\title{
Synthesis of 4-Chloro-N, N-Dimethyl Pyridine Car Box Amide
}

\author{
Yongli Duan, Zhimin $\mathrm{Li}^{\mathrm{a}}$, Qidong Tang, Rui Li and Shan Xu ${ }^{\mathrm{b}}$
}

School of Pharmacy, Jiangxi Science \& Technology Normal University, Nan chang 330013, China

\author{
a110197421@qq.com, bshanxu9891@126.com
}

Keywords: 4-chloro-N; N-dimethyl pyridine car box amide; Synthesis; Process optimization

\begin{abstract}
Sorafenib (1) in the medical field to show the potential biological activity. Literature on the majority of tumor cells have a high biological activity, such as lymphoma, breast cancer, prostate cancer. However, some synthetic route of Sorafeni has disadvantages, such as low product yield and complicated post-treatment. Therefore, in this paper, the main purpose is to optimize the Sorafeni part of the synthesis route. The effects of reaction reagent, feed and temperature on the yield of the reaction were discussed. The optimized reaction conditions were as follows $\mathrm{SOCl}_{2}$ : $\mathrm{POCl}_{3}=5: 1$ and use $\mathrm{K}_{2} \mathrm{CO}_{3}$ instead of triethylamine. The structures were confirmed by ${ }^{1} \mathrm{H} \mathrm{NMR}$.
\end{abstract}

\section{Introduction}

The incidence of liver cancer is about 20/10000, due to early symptoms of liver cancer is not obvious[1], nearly $80 \%$ of patients is already advanced, half of the world's liver cancer occurred in China, and in China the primary factor in liver cancer Among them, hepatitis B in the first place[2-5], the causative factor with liver cancer in Europe and the United States are very different.4-Chloro-N, N-dimethyl pyridine car box amide is part of the key intermediate in sorafenib, and largely affects the activity of sorafenib, which is a novel multi-targeted oral drug for the treatment of tumors and Sorafenib is a new multi-target anti-tumor drugs[6-10], developed by the German Bayer Pharmaceutical Company, which can act on both tumor cells and tumor blood vessels. It has a dual antitumor effect by inhibiting RAF / MEK / ERK-mediated cell signaling pathways directly by inhibiting tumor cell proliferation[11-12], But also by blocking angiogenin and platelet-derived growth factor receptor block tumor neovascularization formation, and indirectly inhibit tumor cell growth.<smiles>CNC(=O)c1cc(Oc2ccc(NC(=O)Nc3ccc(Cl)c(C(F)(F)F)c3)cc2)ccn1</smiles>

Figure 1. Structures of Sorafenib

\section{Materials and Methods}

NMR spectra were performed using Bruker $400 \mathrm{MHz}$ spectrometers (Bruker Bioscience, Billerica, MA, USA) with TMS as an internal standard. Mass spectra (MS) were taken in ESI mode on Agilent 1100 LC-MS (Agilent, Palo Alto, CA, USA). Elemental analysis was determined on a Carlo-Erba 1106 Elemental analysis instrument (Carlo Erba, Milan, Italy). All the materials were obtained from commercial suppliers and used without purification, unless otherwise specified. Yields were not optimized. TLC analysis was carried out on silica gel plates GF254 (Qindao Haiyang Chemical, China). 


\section{Synthesis of Compounds}

The synthetic route were shown in Scheme 1.<smiles>O=C(O)c1ccccn1</smiles>

1

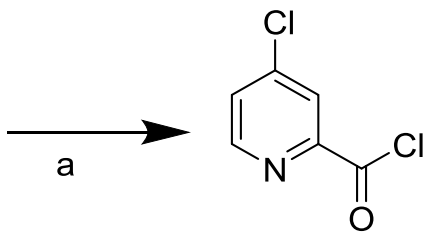

2<smiles>[R]NC(=O)c1ccc(Cl)c(CC)c1</smiles>

$\mathrm{R}=\mathrm{CH}_{3}$ $=\left(\mathrm{CH}_{3}\right)_{2}$

Scheme 1. The synthetic route of compounds $3 a-3 b$

Reagents And Conditions: (a)SOCl2 and POCl3, ,NaBr, chlorobenzene:, $85^{\circ} \mathrm{C}, 15 \mathrm{~h}$; (b) THF, $\mathrm{K} 2 \mathrm{CO} 3$, r. t, 4 h.

Synthesis of 4 - Chloropicolinoyl Chloride(2). To the mixture of $\mathrm{NaBr}(0.023 \mathrm{~g}, 0.0015 \mathrm{~mol})$ and picolinic acid $(10.0 \mathrm{~g}, 0.167 \mathrm{~mol})$, in chlorobenzene $(75 \mathrm{~mL})$. After stirring for $0.5 \mathrm{~h}$ at $50^{\circ} \mathrm{C}$, tdilute $\mathrm{SOCl}_{2}$ and Phosphorus oxychloride was added slowly with stirring maintaining the temperature $50{ }^{\circ} \mathrm{C}$, Raise the temperaturethe to $85{ }^{\circ} \mathrm{C}$. reaction was complete by TLC analysis, 20Filtration, take filtrate, the filtrate was concentrated under reduced pressure to afford product as a yellow viscous oil and was used for next step without further purification. Yield 93.2\%. MS (ESI): $\mathrm{m} / \mathrm{z}[\mathrm{M}+\mathrm{H}]^{+} 177.96$.

Synthesis of 4-chloro-N, N-dimethylpicolinamide(3a-3b). The $\mathrm{CH}_{2} \mathrm{Cl}_{2}(80 \mathrm{~mL})$ was transferred to a beaker and 4-chloropicolinoyl chloride $(1.34 \mathrm{~g}, 0.357 \mathrm{~mol})$ was slowly added with stirring for 15 minutes at a temperature below $0^{\circ} \mathrm{C}$, then $30 \%$ dimethylamine was dropping at room temperature and the reaction was maintained at $0{ }^{\circ} \mathrm{C}$ for 4.5 hours. The reaction was complete by TLC analysis. The reaction mixture was poured onto Ethyl acetate The organic phase was separated ,then concentrated it under reduced pressure to afford product as a yellow viscous oil, Yield : 86\%. ${ }^{1} \mathrm{H}$ NMR (400 MHz, DMSO) $\delta 8.52(\mathrm{~d}, J=5.4 \mathrm{~Hz}, 1 \mathrm{H}), 7.65(\mathrm{~d}, J=1.3 \mathrm{~Hz}, 1 \mathrm{H})$, $7.53(\mathrm{~m}, 1 \mathrm{H}), 2.97(\mathrm{~s}, 3 \mathrm{H}), 2.89(\mathrm{~d}, J=8.0 \mathrm{~Hz}, 3 \mathrm{H}) . \mathrm{MS}(\mathrm{ESI}): \mathrm{m} / \mathrm{z}[\mathrm{M}+\mathrm{H}]{ }^{+} 181.3$

4-chloro-N-methylpicolinamide(3b). Yellow Oily liquid. Yield 87\%. MS (ESI): m/z [M+H] ${ }^{+}$ 171.5

\section{Results and Discussion}

Effect of Solvent Type on Yield of Compound 2. Synthesis of 4 - chloropicolinoyl chloride, the reagents used $\mathrm{SOCl}_{2}$ in the literature, but the reaction there are some shortcomings, such as long reaction time, high temperature, and the yield is not high. Therefore, the authors intend to use $\mathrm{SOCl}_{2}$ and Phosphorus oxychloride in combination as reagents. The data are shown in Table 1.

Table 1 Effect of solvent type

\begin{tabular}{cccc}
\hline reagent & reaction time & temperature & yield \\
\hline $\mathrm{SOCl}_{2}$ & $28 \mathrm{~h}$ & $100^{\circ} \mathrm{C}$, & $76 \%$ \\
$\mathrm{SOCl}_{2}: \mathrm{POCl}_{3}=5: 1$ & $15 \mathrm{~h}$ & $85^{\circ} \mathrm{C}$, & $93.2 \%$ \\
\hline
\end{tabular}

Effect of Reagent on Yield in Synthetic Route of Compounds 3. Synthesis of 4-chloro-N, $\mathrm{N}$-dimethyl picolinic acid amide in the literature used for the triethylamine triethylamine, but the use of more triethylamine, resulting in waste of reagents, a long reaction time, the temperature is difficult to control, Not high shortcomings. Therefore, the authors intend to use $\mathrm{K}_{2} \mathrm{CO}_{3}$ instead of triethylamine. The experimental results are shown in Table 2. 
Table 2 Effect of reagent

\begin{tabular}{ccc}
\hline reagent & reaction time & yield \\
\hline $\mathrm{N}^{\left(\mathrm{C}_{2} \mathrm{H}_{5}\right)_{3}}$ & $28 \mathrm{~h}$ & $78.2 \%$ \\
$\mathrm{~K}_{2} \mathrm{CO}_{3}$ & $4.5 \mathrm{~h}$ & $8 \%$ \\
\hline
\end{tabular}

\section{Conclusions}

In general, 4-chloro-N, N-dimethylpyridinecarboxamide is synthesized by including chlorination, nucleophilic substitution. Through the synthesis method optimization, shorten the reaction time, the temperature is relatively mild, less by-products, the target compound yield higher. The structure was confirmed by $1 \mathrm{H}$ NMR.

\section{Acknowledgments}

We gratefully acknowledge the generous support provided by The National Natural Science Funds of Jiangxi Science \& Technology Normal University (2016XJZD007)

\section{References}

[1] Chiou W Y, Chang C M, Tseng K C, et al. Effect of liver cirrhosis on metastasis in colorectal cancer patients: a nationwide population-based cohort study.[J]. Japanese Journal of Clinical Oncology, 2015, 45(2):160-8.

[2] Corey K E, Zheng H, Mendeznavarro J, et al. Serum Vitamin D Levels Are Not Predictive of the Progression of Chronic Liver Disease in Hepatitis C Patients with Advanced Fibrosis[J]. Plos One, 2012, 7(2):e27144.

[3] Yang Y, Forslund A, Remotti H, et al. P53 mutations in primary tumors and subsequent liver metastases are related to survival in patients with colorectal carcinoma who undergo liver resection[J]. Cancer, 2001, 91(4):727-36.

[4] Masaki M, Nakamura K I, Yamamoto W, et al. The Effects of the Hepatitis B Virus and Occupational and Lifestyle Factors on Liver Function Among Workers in Shanghai.[J]. Asian Pacific Journal of Cancer Prevention Apjcp, 2001, 2(3):207-213.

[5] Mendy M E, Kaye S, Roux E L, et al. Application of a Novel, Rapid, and Sensitive Oligonucleotide Ligation Assay for Detection of Cancer-Predicting Mutations in the Precore and Basal Core Promoter of Hepatitis B Virus[J]. Journal of Clinical Microbiology, 2008, 46(8):2723-30.

[6] Kuzuya T, Ishigami M, Ishizu Y, et al. Early Clinical Response after 2 Weeks of Sorafenib Therapy Predicts Outcomes and Anti-Tumor Response in Patients with Advanced Hepatocellular Carcinoma[J]. Plos One, 2015, 10(9).

[7] Ou D L, Chang C J, Jeng Y M, et al. Potential synergistic anti-tumor activity between lenalidomide and sorafenib in hepatocellular carcinoma.[J]. Journal of Gastroenterology and Hepatology, 2014, 29(12):2021-31.

[8] Zhou C. Multi-targeted tyrosine kinase inhibitors for the treatment of non-small cell lung cancer: an era of individualized therapy.[J]. Translational Lung Cancer Research, 2012, 1(1):72-7.

[9] Cheng X, Thorpe P E. Abstract 3643: Phosphatidylserine-targeting antibody combined with Sorafenib has strong anti-tumor activity against human hepatocellular carcinomas in mice[J]. Cancer Research, 2011, 71(8 Supplement):3643-3643. 
[10].Villeneuve J, Tremblay P, Vallières L. Tumor necrosis factor reduces brain tumor growth by enhancing macrophage recruitment and microcyst formation.[J]. Cancer Research, 2005, 65(9):3928-36.

[11]El-Naggar M M, Mousa S A. Prevention and treatment of tumor growth, metastasis, and thromboembolic complications in cancer patients: US, US6908907[P]. 2005.

[12] Jouanneau J, Moens G, Bourgeois Y, et al. A minority of carcinoma cells producing acidic fibroblast growth factor induces a community effect for tumor progression. [J]. Proceedings of the National Academy of Sciences of the United States of America, 1994, 91(1):286-290. 